\title{
Behavior pattern of beef heifers supplemented with different energy sources on oat and ryegrass pasture
}

\author{
Luiz Angelo Damian Pizzuti ${ }^{1}$, Dari Celestino Alves Filho ${ }^{1}$, Ivan Luiz Brondani ${ }^{1}$, Paulo \\ Santana Pacheco ${ }^{1}$, Leandro da Silva Freitas ${ }^{1}$, Luciane Rumpel Segabinazzi ${ }^{1}$, Álisson Marian \\ Callegaro $^{1}$, Odilene de Souza Teixeira ${ }^{1}$
}

\footnotetext{
${ }^{1}$ Departamento de Zootecnia - Universidade Federal de Santa Maria.
}

ABSTRACT - The objective of this study was to evaluate behavior patterns of heifers grazing on black oat (Avena strigosa Schreb.) and ryegrass (Lolium multiflorum Lam.), fed supplementation with brown rice meal and/or protected fat. A total of 28 Charolais $\times$ Nellore crossbred heifers at average initial age of 18 months and with initial live weight of $274.9 \pm 4.97 \mathrm{~kg}$ were used in the experiment. Animals were kept in oat + ryegrass pastures and distributed in the following treatments: no supplementation; Megalac (MEG): protected fat supplementation; supplementation with brown rice meal (BRM); and supplementation with BRM + MEG. The neutral detergent fiber (NDF) intake of pasture either in kg or in percentage of live weight was not changed by supply of supplement, but increased linearly (0.045 kg per day) over grazing periods. Supplementation with BRM and BRM + MEG reduced grazing time, 49.63\%, in relation to non-supplemented animals and animals supplemented with MEG, 63.13\%. Feeding seasons per minute increased over the experimental period with reduction in time spent in each feeding station. The number of bites per feeding station decreased linearly, with a variation of $34.48 \%$ in the late grazing period. Heifers supplemented with BRM and BRM + MEG require less time for grazing and increase their idle time, with no modification in displacement patterns within the paddocks and pasture ingestion. Grazing and idle time does not change in the distinct periods of pasture use, but rumination time increases with days of pasture use and with increase in NDF intake.

Key Words: feeding stations, grazing, idle, neutral detergent fiber, number of bites, rumination

\section{Introduction}

The main objective of the beef cattle productive activity is centered in two aspects: to obtain the greatest amount of weaned calves and $\mathrm{kg}$ of beef per year. Therefore, the use of temperate climate annual pastures such as oat and ryegrass, which are known for their productive and chemical quality potential, is very important. Because the objective of any system is to achieve the maximum productive potential, the knowledge of cattle behavior factors may help in the management and decision making in pasture based production systems, especially to understand the control of intake by the animals (Macari et al., 2007). For Gontijo Neto et al. (2006), achieving high gains per animal depends on optimization of forage intake, which is influenced, in pasture situations, by multiple factors, which are grouped according to the environment, animal and pasture.

Knowledge of pasture process mechanisms is also important to understanding the control of animal intake (Macari et al., 2007). Information of animal behavior and its location can be used to set sites and environments to be used by the animals and balance them in function of their needs (Carvalho et al., 2009). For an efficient pasture use, it is necessary that there be knowledge of the relationships existing in the plant-animal interface, which involves the study on how pasture conditions interfere in the ingestive behavior of the animal and in its performance in order to identify management conditions fitted to the animal status and to the production system used (Roman et al., 2007).

When animals are supplemented, new variables interfere in the nutrient intake and are associated with relationships of replacing forage and supplement and/or with the addition in the total dry matter intake, which change according to the characteristics of the forage base and of the supplement (Hodgson, 1990). Adams (1985) reported a decrease in grazing time when animals were supplemented with corn; however, with no difference in time spent with rumination.

Thus, the objective of this study was to evaluate the behavior pattern of heifers grazing on oat + ryegrass, fed supplementation with brown rice meal and/or protected fat. 


\section{Material and Methods}

The experiment was carried out in the Beef Cattle Laboratory in the Department of Animal Science of Universidade Federal de Santa Maria. This area is located in the Central Depression of Rio Grande do Sul, at $95 \mathrm{~m}$ of altitude, latitude $29^{\circ} 43^{\prime}$ South and longitude $53^{\circ} 42^{\prime}$ West. The soil of the experimental area belongs to the São Pedro mapping unit and is classified as paleaudalf (Embrapa, 1999). The climate in the region is $\mathrm{Cfa}$ (subtropical humid), according to the Köppen classification (Table 1).

The experimental area corresponded to $16.3 \mathrm{ha}$, of which 11.7 ha were divided into 12 paddocks with variable area, where control animals were managed, and 4.6 ha, where regulating animals were kept. Pasture implementation occurred on April 1st, 2009 with broadcast sowing of $31.2 \mathrm{~kg} / \mathrm{ha}$ of ryegrass (Lolium multiflorum Lam.) seeds based on $100 \%$ of cultural value, and on April 2nd, 3rd and 4 th, 2009 , with in row sowing of $77.4 \mathrm{~kg} / \mathrm{ha}$ of black oat (Avena strigosa Schreb.), with seeds based on $100 \%$ of cultural value.

Pasture establishment took 70 days, when animals entered the pastures. Fifteen days before the experimental period were used for adaptation to the supplement and to the management. The experimental period lasted 112 days, from July 5 th to October 24th, 2009, divided in four 28-day periods.

A total of 28 Charolais $\times$ Nellore crossbred heifers, at initial average age of 18 months and with initial average live weight of $274.9 \pm 4.97 \mathrm{~kg}$ were distributed into the following treatments: no supplementation: heifers kept exclusively on oat + ryegrass pastures; Megalac (MEG): heifers kept on oat + ryegrass pasture fed $3 \%$ of protected fat under estimate of total dry matter intake, set at $30 \mathrm{~g} / \mathrm{kg}$ of live weight; brown rice meal (BRM): heifers kept on oat + ryegrass pastures, fed brown rice meal at the level of $8 \mathrm{~g} / \mathrm{kg}$ of live weight; brown rice meal + Megalac (BRM + MEG): heifers kept on oat + ryegrass pastures fed brown rice meal at the level of $8 \mathrm{~g} / \mathrm{kg}$ of live weight plus $3 \%$ of protected fat under total estimate of dry matter set at $30 \mathrm{~g} / \mathrm{kg}$ of live weight.

Animal behavior was observed in two paddocks of each treatment, with two to the three animals each one, totaling five observed animals per treatment in each evaluation period. The ingestive behavior of animals was carried out on July 28th, September 22nd and October 20th, 2009 for 12 continuous hours, starting at 6:30 a.m. and finishing at 6:30 p.m. Grazing, idle and rumination activities were recorded in minutes, at every 10 minutes. According to Castro (2002), grazing time is the period when the practice of forage ingestion by the animals takes place, in which small displacements are included. Rumination time was considered the period when the animal was not grazing, but chewing bolus regurgitated from the rumen. Idle time was the period when the animal was neither grazing nor ruminating, but social activities and water ingestion are included.

Bite rate was determined during grazing periods, considered as the time spent by the animal to perform 20 bites (Hodgson, 1982), and then corrected for one minute by the following equation: bite rate $/ \mathrm{min}=20 * 60 /$ time spent to take 20 bites. The time each heifer used to go through ten feeding stations and the number of steps between those stations was registered over the 12 observation hours, in distinct grazing intervals.

Feeding station was defined when animals were grazing, not moving their front feet but sometimes moving their heads (Laca et al., 1992). The calculation of the number of stations per minute and displacement rate (steps/minute) was done from the variables previously cited. Number of bites per station was calculated by dividing the sum of bite rate per minute by the sum of number of feeding stations per minute.

Forage mass was determined by the double sampling technique (Wilm et al., 1944), at the beginning of the period and then every 14 days. In each repetition, five $0.25 \mathrm{~m}^{2}$ cuts at the soil level and 20 visual estimates were done. A sample was taken from each cut for the formation of a composite

Table 1 - Minimum, maximum and mean temperatures, wind speed and relative air humidity (RAH) on the days of beef heifer behavior evaluation

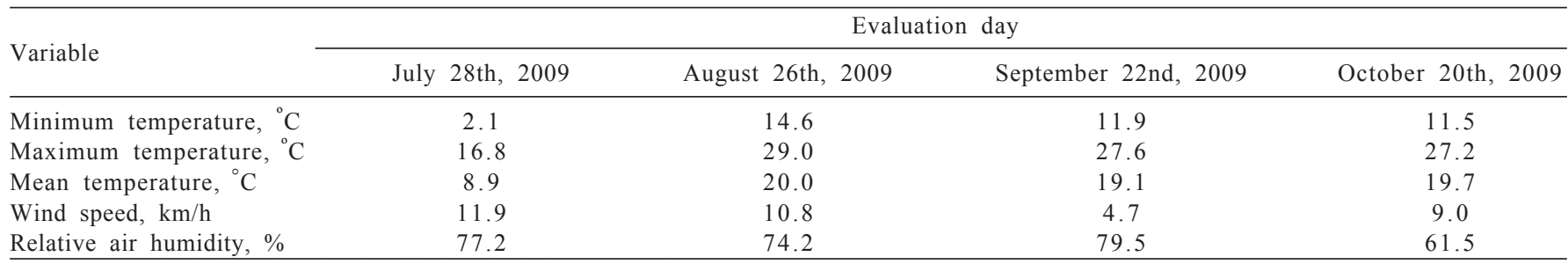

Source: Meteorological Station of Universidade Federal de Santa Maria (2010). 
sample. Forage from the composite sample was homogenized and divided into two sub-samples, one for dry matter (DM) content determination, and the other for manual separation of botanical components of the pasture.

The method adopted was continuous grazing with variable stocking rate, through the "put and take" technique (Mott \& Lucas, 1952), by using a pre-determined forage mass of $1.200 \mathrm{~kg} \mathrm{DM} / \mathrm{ha}$. Therefore, regulator animals were kept in an area attached to the experiment area with oat + ryegrass pastures. To adequate the capacity of animal support and the target forage mass, a forage disappearance rate of $45 \mathrm{~g} / \mathrm{kg} \mathrm{DM}(30 \mathrm{~g} / \mathrm{kg}$ DM intake $+15 \mathrm{~g} / \mathrm{kg}$ DM of losses) was considered. For calculation of the estimate of DM intake per treatment and period, final forage mass of the period and forage losses over the period were subtracted from total production of DM/ha in the period. Dry matter intake was obtained in $\mathrm{g} / \mathrm{kg}$ of live weight for each period by dividing the estimated intake of $\mathrm{DM} /$ ha by the capacity of animal support in the period.

Based on the values of forage mass, pasture accumulation rate, and capacity of animal support, forage supply (Table 2) was determined in $\mathrm{kg}$ of DM/100 kg of LW through the equation: $\mathrm{FS}=((((\mathrm{iFM}+\mathrm{fFM}) / 2) /$ number of days $)+\mathrm{AR}) / \mathrm{CA} * 100$, in which $\mathrm{FS}=$ forage supply in the period; $\mathrm{iFM}=$ initial forage mass in the period; $\mathrm{fFM}=$ final forage mass in the period; $\mathrm{AR}=$ daily $\mathrm{DM}$ accumulation rate in the period; $\mathrm{CA}=$ capacity of animal support in the period. Leaf blade supply was achieved by multiplying the percentage of leaf blades by forage supply.

For sampling of forage consumed by heifers, grazing simulation was carried out in each experimental period, when two trained evaluators, after observation of 15 minutes of ingestive behavior of animals, collected approximately $0.4 \mathrm{~kg}$ of forage material similar to the ones collected by the animals (Euclides et al., 1992). Samples were pre-dried in forced air circulation oven at $55{ }^{\circ} \mathrm{C}$, for 72 hours, until constant weight, when grinding was done in a Willey type mill with $1 \mathrm{~mm}$ mesh sieve. The dry matter content was determined by drying in an oven at $105^{\circ} \mathrm{C}$ until constant weight. The neutral detergent fiber content was determined according to Van Soest et al. (1991).

The experimental design was completely randomized, with three replicates per area, in a $4 \times 4$ factorial arrangement (four treatments $\times$ four periods). Data were tested for normality by using the Shapiro-Wilk test, with behavior variables time/feeding station and bite rate transformed by logarithms. Afterwards, analyses of variance and $\mathrm{F}$ test at the level of $5 \%$ of significance were done, through command PROC MIXED, and the AIC was the information criterion for choosing the best structure of covariance; when difference between means was detected, they were compared by Student's t test.

Table 2 - Chemical and structural characteristics of oat + ryegrass pastures

\begin{tabular}{|c|c|c|c|c|c|}
\hline \multirow[b]{2}{*}{ Variable } & \multicolumn{4}{|c|}{ Supplement type } & \multirow[b]{2}{*}{$\begin{array}{c}\text { Standard } \\
\text { error }\end{array}$} \\
\hline & o-supplementation & Megalac & Brown rice meal & $\begin{array}{l}\text { Brown rice meal } \\
\quad+\text { Megalac }\end{array}$ & \\
\hline Dry matter (DM), $\mathrm{g} / \mathrm{kg}$ & 185.6 & 185.6 & 185.1 & 179.8 & 0.51 \\
\hline $\mathrm{NDFa}, \mathrm{g} / \mathrm{kg}$ & 400.5 & 404.6 & 423.5 & 401.7 & 0.81 \\
\hline Forage mass, $\mathrm{kg} \mathrm{DM} / \mathrm{ha}$ & 1399.86 & 1189.50 & 1233.61 & 1202.93 & 73.41 \\
\hline Forage supply, $\mathrm{kg} \mathrm{DM} / 100 \mathrm{~kg} \mathrm{LW}$ & $11.44 \mathrm{a}$ & $10.72 b$ & $10.45 b$ & $9.76 \mathrm{c}$ & 0.21 \\
\hline Leaf blade supply, $\mathrm{kg} \mathrm{DM} / 100 \mathrm{~kg} \mathrm{LW}$ & 4.39 & 4.27 & 4.00 & 3.88 & 0.17 \\
\hline Leaf/stem ratio & 1.30 & 1.46 & 1.31 & 1.46 & 0.11 \\
\hline \multirow[t]{2}{*}{ Total DM intake, $\mathrm{g} / \mathrm{kg}$} & 39.20 & 41.00 & 45.00 & 41.70 & 0.33 \\
\hline & \multicolumn{4}{|c|}{ Period } & \multirow[b]{2}{*}{ Mean } \\
\hline Variable & $\begin{array}{l}\text { July 5th - } \\
\text { August 1st }\end{array}$ & $\begin{array}{l}\text { August 2nd - } \\
\text { August 29th }\end{array}$ & $\begin{array}{l}\text { August } 30 \text { th - } \\
\text { September } 26 \text { th }\end{array}$ & $\begin{array}{l}\text { September } 27 \text { th - } \\
\text { October } 24 \text { th }\end{array}$ & \\
\hline Dry matter, $\mathrm{g} / \mathrm{kg}^{1}$ & 188.4 & 176.7 & 168.2 & 202.7 & 184.4 \\
\hline $\mathrm{NDFa}, \mathrm{g} / \mathrm{kg}^{2}$ & 379.1 & 397.9 & 432.4 & 420.9 & 407.3 \\
\hline Forage mass, $\mathrm{kg} \mathrm{DM} / \mathrm{ha}$ & 1148.78 & 1248.69 & 1296.31 & 1335.10 & 1245.02 \\
\hline Forage supply, $\mathrm{kg}$ DM/100 kg LW & 10.28 & 11.15 & 9.78 & 11.11 & 10.45 \\
\hline Leaf blade supply, $\mathrm{kg} \mathrm{DM} / 100 \mathrm{~kg} \mathrm{LW}{ }^{3}$ & 40.0 & 51.7 & 42.4 & 31.1 & 41.7 \\
\hline Leaf/stem ratio $^{4}$ & 1.12 & 1.96 & 1.72 & 0.72 & 1.27 \\
\hline Pasture intake, $\mathrm{g} / \mathrm{kg}^{5}$ & 29.2 & 42.5 & 36.6 & 46.6 & 38.7 \\
\hline
\end{tabular}

Means followed by different letter in the row differ by the t Test $(\mathrm{P}<0.05)$.

LW - live weight; NDFa - ash-free neutral detergent fiber; CV - coefficient of variation.

${ }^{1} \mathrm{Y}=163.65+2.0111 *$ Day-0.0486* Day $^{2}+0.0003017^{*}$ Day $^{3}\left(\mathrm{R}^{2}=0.56 ; \mathrm{CV}=6.47 \% ; \mathrm{P}=0.0179\right)$

${ }^{2} \mathrm{Y}=367.6208+0.5698 *$ Day $\left(\mathrm{R}^{2}=0.27 ; \mathrm{CV}=7.33 \% ; \mathrm{P}=0.0002\right)$.

${ }^{3} \mathrm{Y}=19.399+0.9832 *$ Day-0.0078967* Day $^{2}\left(\mathrm{R}^{2}=0.41 ; \mathrm{CV}=21.73 \% ; \mathrm{P}<0.0001\right)$.

${ }^{4} \mathrm{Y}=-0.55563+0.07691 *$ Day $-0.00058594 * \mathrm{Day}^{2}\left(\mathrm{R}^{2}=0.72 ; \mathrm{CV}=22.52 \% ; \mathrm{P}<0.0001\right)$

${ }^{5} \mathrm{Y}=27.1542+0.1665 *$ Day $\left(\mathrm{R}^{2}=0.18 ; \mathrm{CV}=28.63 \% ; \mathrm{P}=0.0023\right)$. 
The mathematical model adopted in the analysis of variance was the following:

$$
\mathrm{Y}_{\mathrm{ijk}}=\mu+\mathrm{T}_{\mathrm{i}}+\mathrm{R}_{\mathrm{k}}\left(\mathrm{T}_{\mathrm{i}}\right)+\mathrm{P}_{\mathrm{j}}+(\mathrm{TP})_{\mathrm{ij}}+\mathrm{e}_{\mathrm{ijk}}
$$

in which: $Y_{i j k}=$ dependent variables; $\mu=$ mean of all observations; $T_{i}=$ effect of the $i$-th feeding treatment; $R_{k}$ $\left(\mathrm{T}_{\mathrm{i}}\right)=$ effect of the $\mathrm{k}$-th repetition in the $\mathrm{i}$-th treatment (error a); $P_{j}=$ effect of the $j$-th period; $(T P)_{i j}=$ interaction between the ith treatment and the $\mathrm{j}$-th period; and $\mathrm{e}_{\mathrm{ijk}}=$ total experimental error (error b).

Correlation test and polynomial regression were performed at the level of $5 \%$ of significance. Data analyses were carried out by using statistical package SAS (Statistical Analysis System, version 8.1).

\section{Results and Discussion}

There was no interaction between treatment and period for different manners of expression of neutral detergent fiber intake of the pasture (Table 3 ).

The neutral detergent fiber intake of the pasture either in $\mathrm{kg}$ or in relation to body weight was not altered $(\mathrm{P}>0.05)$ by supplement supply. Those results differ from the ones reported by Silva et al. (2010), who fed heifers grazing Brachiaria brizantha cultivar Marandu with mineral salt and energy and protein supplementation at the levels of 3 , 6 and $9 \mathrm{~g} / \mathrm{kg}$ of body weight and found a reduction in NDF ingestion due to the observed replacement effect. Over grazing periods, NDF intake increased linearly $(\mathrm{P}<0.05)$ by $0.046 \mathrm{~kg}$ per day, following the tendency observed in the chemical analyses (Table 2), which presented an increase of $0.57 \mathrm{~g} / \mathrm{kg}$ more dry matter in the NDF content as the experimental period advanced.

Supplementation with BRM and BRM+MEG reduced the time spent by grazing heifers in relation to heifers kept exclusively on pastures and which were fed MEG by $21 \%$ (Table 4).

Even when heifers were fed MEG, the small amount supplied, $3 \%$ over dry matter intake, did not presented any effect under grazing activity. Over the 12 day-hours of evaluation, $63.13 \%$ of the time was assigned for grazing activities of the NS and MEG heifers, and $49.63 \%$ were for grazing activities of heifers fed BRM and BRM + MEG. It was found that even with the difference in grazing, the time of rumination did not change, and reduction in grazing time by supplementation with BRM and BRM + MEG increased the idle time of the animals. Silva et al. (2010) found variations in grazing and idle activities as the supplementation level increased but with no alteration in rumination time.

Table 3 - Absolute intake and in relation to body weight of neutral detergent fiber of oat + ryegrass pasture according to treatment and period of pasture utilization

\begin{tabular}{|c|c|c|c|c|c|c|}
\hline \multirow[b]{2}{*}{ Intake } & \multicolumn{4}{|c|}{ Supplement types } & \multirow[b]{2}{*}{ Mean } & \multirow[b]{2}{*}{$\begin{array}{c}\text { Standart } \\
\text { error }\end{array}$} \\
\hline & No-supplementation & Megalac & Brown rice meal & $\begin{array}{l}\text { Brown rice meal } \\
\quad+\text { Megalac }\end{array}$ & & \\
\hline Neutral detergent fiber, kg & 5.54 & 5.69 & 5.48 & 4.85 & 5.49 & 0.52 \\
\hline Neutral detergent fiber, $\mathrm{g} / \mathrm{kg}$ & 15.70 & 16.60 & 16.00 & 13.80 & 15.80 & 0.14 \\
\hline \multirow[b]{2}{*}{ Intake } & \multicolumn{4}{|c|}{ Grazing period } & \multirow[t]{2}{*}{ Mean } & \\
\hline & $\begin{array}{l}\text { July 5th - } \\
\text { August 1st }\end{array}$ & $\begin{array}{l}\text { August 2nd - } \\
\text { August 29th }\end{array}$ & $\begin{array}{l}\text { August 30th - } \\
\text { Septmeber 26th }\end{array}$ & $\begin{array}{l}\text { September } 27 \text { th }- \\
\text { October } 24 \mathrm{th}\end{array}$ & & \\
\hline Neutral detergent fiber, $\mathrm{kg}^{1}$ & 3.29 & 5.51 & 5.63 & 7.61 & 5.49 & \\
\hline Neutral detergent fiber, $\mathrm{g} / \mathrm{kg}^{2}$ & 11.20 & 17.00 & 14.50 & 19.50 & 15.80 & \\
\hline
\end{tabular}

$\mathrm{CV}$ - coefficient of variation

${ }^{1} \mathrm{Y}=2.24+0.04667 *$ Day $\left(\mathrm{R}^{2}=0.44 ; \mathrm{CV}=30.77 \% ; \mathrm{P}<0.0001\right)$

${ }^{2} \mathrm{Y}=9.9542+0.0846 *$ Day $\left(\mathrm{R}^{2}=0.25 ; \mathrm{CV}=29.76 \% ; \mathrm{P}=0.0003\right)$

Table 4 - Time spent grazing, idle, in rumination and at the trough (in minutes), in heifers, for 12 hours of evaluation

\begin{tabular}{|c|c|c|c|c|c|c|}
\hline \multirow[b]{2}{*}{ Variable } & \multicolumn{4}{|c|}{ Supplement type } & \multirow[b]{2}{*}{ Mean } & \multirow[b]{2}{*}{$\begin{array}{c}\text { Standart } \\
\text { error }\end{array}$} \\
\hline & No-supplementation & Megalac & Brown rice meal & $\begin{array}{l}\text { Brown rice meal } \\
\quad+\text { Megalac }\end{array}$ & & \\
\hline Grazing & $442.0 \mathrm{a}$ & $467.0 \mathrm{a}$ & $349.0 \mathrm{~b}$ & $368.5 \mathrm{~b}$ & 406.62 & 9.28 \\
\hline Idle & $169.0 \mathrm{~b}$ & $145.0 \mathrm{~b}$ & $230.5 \mathrm{a}$ & $204.0 \mathrm{a}$ & 187.12 & 10.16 \\
\hline Rumination & 109.0 & 106.0 & 107.5 & 114.0 & 109.12 & 8.41 \\
\hline Trough & - & $3.0 \mathrm{~b}$ & $33.5 \mathrm{a}$ & $33.5 \mathrm{a}$ & 23.3 & 2.94 \\
\hline
\end{tabular}

Means followed by different letters in the row differ $(\mathrm{P}<0.0001)$, by the $\mathrm{t}$ test. 
According to Moreno et al. (2008), supplementation with corn meal at the level of $10 \mathrm{~g} / \mathrm{kg}$ of the body weight for calves grazing year ryegrass decreased grazing time and increased idle time with no effect on rumination, probably in function of the existence of the supplement replacement effect by pasture. The same authors found that grazing time for nonsupplemented heifers corresponded to $409.02 \mathrm{~min}$, and when they were supplemented, the time was $342.5 \mathrm{~min}$. The grazing time found in this study is longer than the one reported by Macari et al. (2007) with animals kept exclusively on pastures, $442.0 \mathrm{vs}$. $410.75 \mathrm{~min}$, and for supplemented animals, it was $358.75 \mathrm{vs} 294.92 \mathrm{~min}$. The permanence of animals supplemented with BRM and BRM + MEG at the trough for a longer period was due to the greater supply of $\mathrm{kg}$ of supplements to the respective treatments, in relation to MEG-supplemented animals. The time of permanence at the trough for the level of supplementation used, $8 \mathrm{~g} / \mathrm{kg}$ of body weight, was very close to the one found by Pardo et al. (2003) with supplementation level of $7.5 \mathrm{~g} / \mathrm{kg}$ of body weight on native pasture, $32.4 \mathrm{~min}$, and it met the one reported by Dulphy \& Faverdin (1987) for ingestion time of concentrates which varied from 10 to $25 \mathrm{~min} / \mathrm{kg}$ of dry matter.

There was no interaction between treatment and period $(\mathrm{P}>0.05)$ for variables displacement and forage ingestion by heifers (Table 5), and no variables were significantly influenced by the type of supplement supplied. Even with differences in the time spent by heifers on the pastures, which was lower for treatments BRM and BRM + MEG, it is likely that maintenance of the same forage mass, leaf/stem ratio and leaf blade supply among treatments (Table 2) determined the non-existence of differences of displacement and ingestion.

The permanence of the heifers at feeding stations presented an average of 8.51 seconds, which is a result expressively lower than the 18.62 seconds reported by Trevisan et al. (2005) with steers kept at two levels (350 and $600 \mathrm{~kg} \mathrm{DM} / \mathrm{ha}$ ) of green leaf blade biomass on oat + ryegrass pastures. Those authors cite that accessibility of green leaves at pasture superficial heights, by its spatial distribution, and the leaf:stem ratio over pasture growth cycle may interfere in the time that the animal uses for forage ingestion at a grazing station.

As there was no difference $(\mathrm{P}>0.05)$ in the time spent at each feeding station, and the amount of bites performed at the feeding station, an average of 8.49 bites, the number of feeding stations per minute remained the same among treatments with no interference in the bite rate per minute. According to Rovira (1996), when the availability of the forage which the animal searches for eating is twice as much as what it needs, a progressive reduction occurs at the quantity of daily forage consumed, and this process is followed by a reduction in the grazing time, number of bites and size of each bite. Once forage supply was always above the double of the needs of the heifers and leaf blade supply did not present any differences (Table 2), bite rate remained unchanged among treatments. Moreover, supplementation also did not affect bite rate, which is in agreement with Bremm et al. (2008), who did not find influence in bite rate with inclusion of increasing, decreasing and fixed levels of concentrate for lambs, so, the average, $57.1 \mathrm{bites} / \mathrm{min}$, remained very close to the one found in this study. The number of feeding stations per minute presented correlation of $-0.92(\mathrm{P}<0.0001)$ and $-0.89(\mathrm{P}<0.0001)$ for time spent per feeding station and number of bites per feeding station, respectively, and the correlation between the latter two was $0.94(\mathrm{P}<0.0001)$.

The time spent by the heifer in grazing activity was not altered by the increase in period of pasture use (Table 6), even with the difference in the chemical and structural composition of pasture in the different periods (Table 2). Because forage mass was similar between all periods and leaf blade supply and the leaf:stem ratio presented a small variation in the last period in relation to the first period of evaluation, grazing time was constant, especially because there were no factors limiting pasture intake (Table 2).

Table 5 - Stations per minute, steps per minute, time per stations, bite rate and bites per station of heifers grazing oat + ryegrass, fed different supplements

\begin{tabular}{|c|c|c|c|c|c|c|}
\hline \multirow[b]{2}{*}{ Variable } & \multicolumn{4}{|c|}{ Supplement type } & \multirow[b]{2}{*}{ Mean } & \multirow[b]{2}{*}{$\begin{array}{c}\text { Standart } \\
\text { error }\end{array}$} \\
\hline & No-supplementation & Megalac & Brown rice meal & $\begin{array}{c}\text { Brown rice meal } \\
+ \text { Megalac }\end{array}$ & & \\
\hline Station/minute & 8.62 & 7.84 & 7.13 & 8.03 & 7.95 & 0.48 \\
\hline Steps/minute & 11.00 & 12.75 & 10.05 & 11.67 & 11.37 & 0.74 \\
\hline Time/station & 7.84 & 8.58 & 9.28 & 8.36 & 8.51 & 0.02 \\
\hline Bite rate/minute & 63.47 & 59.32 & 62.49 & 62.07 & 61.84 & 1.39 \\
\hline Bite/station & 7.80 & 8.11 & 9.18 & 8.19 & 8.49 & 0.50 \\
\hline
\end{tabular}


The grazing time in different periods was not influenced when increasing and decreasing levels of concentrate were offered to the heifers; however, grazing time varied for nonsupplemented animals and the ones which were fed fixed supplementation (Bremm et al., 2008). Those authors also conclude that the ingestive behavior of beef heifers grazing oat and ryegrass varied according to supplementation strategies and characteristics of pasture.

During day time, $56.47 \%$ of the time spent by heifers corresponded to grazing activity; idle time was represented by $25.99 \%$ of the time, with no differences between periods. However, rumination time was influenced $(\mathrm{P}<0.05)$ by grazing period, which was best represented by the equation $\mathrm{Y}=86.0+0.5875 *$ Day $\left(\mathrm{R}^{2}=0.32 ; \mathrm{P}<0.0001\right)$, concomitant with the growing increase in the NDF intake in $\mathrm{g} / \mathrm{kg}$, but correlation was only found with NDF intake in $\mathrm{kg}(\mathrm{r}=0.29$; $\mathrm{P}=0.0194$ ).

For Baggio et al. (2008), grazing time differed between the evaluated stages, increasing from 360 to 460 minutes of vegetative stage to reproductive stage, possibly due to the increase in the proportion of components of senescent material and inflorescence in the structure of the pasture and to the significant decrease in the amount of leaf blade mass, which can reduce quality and increase selectivity, making it necessary to increase grazing time. The time animals remained at the trough did not differ $(\mathrm{P}>0.05)$ over grazing time despite the greater amount of supplement in $\mathrm{kg}$ as the experiment advanced, i.e., the ingestive capacity of cattle becomes proportional to its body development, so animals with greater body weight at the end of the grazing period on oat + ryegrass pastures present trough behavior equal to when they presented lower weight at the beginning of the experiment, but with concentrate supply equally proportional to its live weight at the two distinct moments.

The search for different feeding stations per minute grew increasingly over the experimental period with reduction in the time spent in each feeding station $(\mathrm{P}<0.05)$ (Table 7).

This occurred due to the modifications in displacement patterns and pasture ingestion by heifers based on the greater number of feeding stations and on the reduction of time between stations with the increase in bite rates due to the increase in forage intake (Table 2) over grazing time.

The number of bites per feeding station decreased linearly, with a variation by $34.48 \%$ less at the end of the grazing period, with increasing bite rate, presenting a

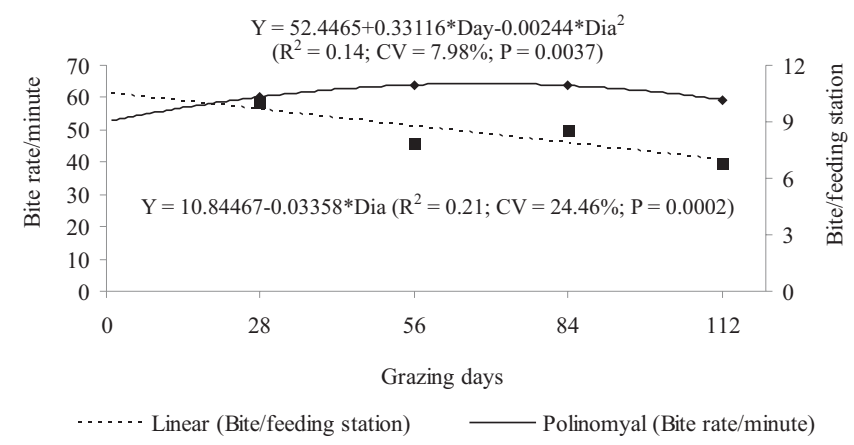

Figure 1 - Bite rate and number of bites per feeding station of heifers grazing oat + ryegrass.

Table 6 - Time spent grazing, idle, in rumination and at the trough (in minutes) in heifers at different periods of oat + ryegrass grazing

\begin{tabular}{|c|c|c|c|c|c|}
\hline \multirow[b]{2}{*}{ Variable } & \multicolumn{4}{|c|}{ Grazing period } & \multirow[b]{2}{*}{ Mean } \\
\hline & $\begin{array}{l}\text { July 5th - } \\
\text { August 1st }\end{array}$ & $\begin{array}{l}\text { August 2nd - } \\
\text { August 29th }\end{array}$ & $\begin{array}{l}\text { August 30th - } \\
\text { September 26th }\end{array}$ & $\begin{array}{c}\text { September } 27 \text { th }- \\
\text { October } 24 \text { th }\end{array}$ & \\
\hline Grazing & 412.5 & 419.5 & 401.0 & 393.5 & 406.62 \\
\hline Idle & 198.5 & 191.5 & 179.0 & 179.5 & 187.12 \\
\hline Rumination ${ }^{1}$ & 88.5 & 94.5 & 118.0 & 135.5 & 109.12 \\
\hline Trough & 27.33 & 19.33 & 29.33 & 17.33 & 23.33 \\
\hline
\end{tabular}

${ }^{1} \mathrm{Y}=86.0+0.5875 \mathrm{X}^{*}$ Day $\left(\mathrm{R}^{2}=0.32 ;\right.$ Coefficient of variation $\left.=24.59 \% ; \mathrm{P}<0.0001\right)$.

Table 7 - Station per minute, steps per minute and time (seconds) per station of heifers at different oat + ryegrass grazing periods

\begin{tabular}{|c|c|c|c|c|c|}
\hline \multirow[b]{2}{*}{ Variable } & \multicolumn{4}{|c|}{ Grazing period } & \multirow[b]{2}{*}{ Mean } \\
\hline & $\begin{array}{l}\text { July 5th - } \\
\text { August 1st }\end{array}$ & $\begin{array}{l}\text { August 2nd - } \\
\text { August 29th }\end{array}$ & $\begin{array}{l}\text { August 30th - } \\
\text { September 26th }\end{array}$ & $\begin{array}{l}\text { September } 27 \text { th }- \\
\text { October } 24 \text { th }\end{array}$ & \\
\hline Station $/ \min ^{1}$ & 6.29 & 8.34 & 7.87 & 9.13 & 7.91 \\
\hline Steps $/ \min ^{2}$ & 14.53 & 10.30 & 10.09 & 10.56 & 11.37 \\
\hline Time (second)/station 3 & 10.34 & 8.03 & 8.45 & 7.24 & 8.51 \\
\hline
\end{tabular}

$\mathrm{CV}$ - coefficient of variation.

${ }^{1} \mathrm{Y}=5.83467+0.02618^{*}$ Day $\left(\mathrm{R}^{2}=0.20 ; \mathrm{CV}=21.68 \% ; \mathrm{P}=0.0003\right)$

${ }^{2} \mathrm{Y}=22.70717-0.31209^{*}$ Day+0.00181* Day $^{2}\left(\mathrm{R}^{2}=0.26 ; \mathrm{CV}=34.88 \% ; \mathrm{P}=0.0082\right)$.

${ }^{3} \mathrm{Y}=10.97267-0.03191 *$ Day $\left(\mathrm{R}^{2}=0.20 ; \mathrm{CV}=23.50 \% ; \mathrm{P}=0.0004\right)$ 
maximum point on day 68, with a later decrease (Figure 1). One manner cattle acquire sufficient amount of nutrients for their survival is by fitting bite rate to grazing time(Provenza etal., 1992). Because forage mass and forage supply (Table 2) were the same in the distinct periods, the variations found in the behavior of the heifers may have been manifested in function of variations in the pasture structure as leaf blade supply and leaf:stem ratio. According to Glienke (2009), alteration in the velocity of ingestion and decision taking to perform one or more bites at the same feeding station was linked especially to structural pasture changes and consequent variation in the chemical composition of the plants. According to Roman et al. (2007), the grazing animal adapts its ingestive behavior so as to maintain its intake even with variation in pasture structure.

\section{Conclusions}

Heifers supplemented with brown rice meal and brown rice meal + Megalac require less grazing time and increase their idle period without changing their displacement patterns within the paddock and pasture ingestion. Grazing and idle time was not altered in the distinct periods of pasture use; however, rumination time increases with the days of pasture use, along with increase in neutral detergent fiber intake, respectively.

\section{Acknowledgements}

The authors thank Química Geral do Nordeste for the supply of Megalac ${ }^{\circledR}$ for the carrying out of this experiment.

\section{References}

ADAMS, D.C. Effect of time of supplementation on performance, forage intake and grazing behavior of yearling beef steers grazing Russian wild ryegrass in the fall. Journal of Animal Science, v.61, p.1037-1042, 1985 .

Baggio, C.; CARVAlHo, P.C.F.; SILVA, J.L.S. et al. Padrões de uso do tempo por novilhos em pastagem consorciada de azevém anual e aveia-preta. Revista Brasileira Zootecnia, v.37, n.11, p.1912-1918, 2008 .

BREMM, C.; ROCHA, M.G.; FREITAS, F.K.F. et al. Comportamento ingestivo de novilhas de corte submetidas a estratégias de suplementação em pastagem de aveia e azevém. Revista Brasileira de Zootecnia, v.37, n.7, p.1161-1167, 2008.

CARVALHO, P.C.F.; TRINDADE, J.K.; MEZZALIRA, J.C. et al. Do bocado ao pastoreio de precisão: compreendendo a interface planta-animal para explorar a multi-funcionalidade das pastagens. Revista Brasileira de Zootecnia, v.38, p.109-122, 2009 (supl. especial).

CASTRO, C.R.C. Relações planta-animal em pastagem de milheto (Pennisetum americanum (1.) Leeke.) manejada em diferentes alturas com bovinos. 2002. 185f. Dissertação
(Mestrado em Zootecnia) - Universidade Federal do Rio Grande do Sul, Porto Alegre.

DULPHY, J.P.; FAVERDIN, P. L'ingestion alimentaire chez les ruminants: modalités et phénomènes associés. Reproduction, Nutrition et Dévelopment, v.27, n.1B, p.129-155, 1987.

EMPRESA BRASILEIRA DE PESQUISA AGROPECUÁRIA EMBRAPA. Centro Nacional de Pesquisa de Solos. Sistema brasileiro de classificação de solos. Brasília: EMBRAPA. Rio de Janeiro, 1999. 412p.

EUCLIDES, V.P.B.; MACEDO, M.C.M.; OLIVEIRA, M.P. Avaliação de diferentes métodos de amostragem sob pastejo. Revista Brasileira de Zootecnia, v.21, n.4, p.691-702, 1992.

GLIENKE, C.L. Ecologia do pastejo de cordeiras em pastagem de azevém e trevo vermelho sob intensidades de desfolha. 2009. 78f. Dissertação (Mestrado em Zootecnia) - Universidade Federal de Santa Maria, Santa Maria.

GONTIJO NETO, M.M.; EUCLIDES, V.P.B.; NASCIMENTO JÚNIOR, D. et al. Consumo e tempo diário de pastejo por novilhos Nelore em pastagem de capim-tanzânia sob diferentes ofertas de forragem. Revista Brasileira de Zootecnia, v.35, n.1, p.60-66, 2006.

HODGSON, J. Ingestive behavior. In: LEAVER, J.D. (Ed.) Herbage intake handbook. Hurley: British Grassland Society, 1982. p.113.

HODGSON, J. Grazing management. Science into practice. England: Longman Scientific \& Technical, 1990. 203p.

LACA, E. A.; UNGAR, E.D.; SELIGMAN, N.G. et al. An integrated methodology for studying short-term grazing behaviour of cattle. Grass and Forage Science, v.47, n.1, p.81-90, 1992.

MACARI, S.; ROCHA, M.G.; PÖTTER, L. et al. Comportamento ingestivo diurno de novilhas de corte recebendo níveis de suplemento. Ciência Rural, v.37, n.6, p.1746-1752, 2007.

MORENO, C.B.; FISCHER, V.; MONKS, P.D. et al. Comportamento ingestivo diurno de novilhas Jersey sob suplementação com farelo de milho em pastagem de azevém anual. Revista Brasileira de Zootecnia, v.37, n.3, p.487-493, 2008.

MOTT, G.O.; LUCAS, H.L. The design conduct and interpretation of grazing trials on cultivated and improved pastures. In: INTERNATIONAL GRASSLAND CONGRESS, 6., 1952, Pennsylvania. Proceedings... Pennsylvania: State College Press, 1952. p.1380-1395.

PARDO, R.M.P.; FISCHER, V.; BALBINOTTI, M. et al. Comportamento ingestivo diurno de novilhos em pastejo submetidos a níveis crescentes de suplementação energética. Revista Brasileira de Zootecnia, v.32, n.6, p.1408-1418, 2003.

PROVENZA, F.D.; PFISTER, J.A.; CHENEY, C.D. et al. Mechanisms of learning in diet selection with reference to phytotoxicosis in herbivores. Journal Range Management, v.45, p.36-45, 1992.

ROMAN, J.; ROCHA, M.G.; PIRES, C.C. et al. Comportamento ingestivo e desempenho de ovinos em pastagem de azevém anual (Lolium multiflorum Lam.) com diferentes massas de forragem. Revista Brasileira de Zootecnia, v.36, n.4, p.780-788, 2007.

ROVIRA, J. Manejo nutritivo de los rodeos de cría en pastoreo. Montevideo: Ed. Hemisfério Sur., 1996. 287p.

SILVA, R.R.; PRADO, I.N.; SILVA, F.F. et al. Comportamento ingestivo diurno de novilhos Nelore recebendo níveis crescentes de suplementação em pastejo de capim-braquiária. Revista Brasileira de Zootecnia, v.39, n.9, p.2073-2080, 2010.

TREVISAN, N.B.; QUADROS, F.L.F.; SILVA, A.C.F. et al. Efeito da estrutura de uma pastagem hibernal sobre o comportamento de pastejo de novilhos de corte. Revista Brasileira de Zootecnia, v.34, n.3, p.774-780, 2005.

VAN SOEST, P.J.; ROBERTSON, J.B.; LEWIS, B.A. Methods for dietary fiber, neutral detergent fiber, and nonstarch polysaccharides in relation to animal nutrition. Journal of Dairy Science, v.74, p.3583-3597, 1991.

Wilm, H.G.; COSTello, D.F.; KLIPPle, G.E. Estimating foragem yield by the double-sampling methods. Journal of American Society of Agronomy, v.36, p.194-203, 1944. 